\title{
A metafísica repensada a partir da tradição fenomenológico-hermenêutica
}

\author{
Metaphysics rethought through hermeneutic \\ phenomenology tradition
}

*Luiz Rohden

Resumo: A metafísica pertence à espinha dorsal da tradição filosófica. O termo, não raro, porém, ainda causa uma espécie de mal-estar no meio acadêmico. Aqui, propomo-nos, inicialmente, mostrar que, de fato, um determinado modelo de metafísico soçobrou. Num segundo momento, justificaremos a retomada da reflexão sobre a metafísica por razões antropológicas e da tradição fenomenológico-hermenêutica, concedendo ênfase às perspectivas francesa e germânica. Ao final, argumentaremos em torno de uma noção de metafísica que deve incorporar, em seu discurso, a temporalidade. É em Ricoeur que encontramos indicações decisivas, próprias da tradição fenomenológico-hermenêutica, que nos possibilitam reconfigurar, num novo e apropriado estilo, a metafísica narrativa que integra a compreensão e a concepção de pessoa em seu bojo.

Palavras-chave: Metafísica. Hermenêutica. Tempo. Ricoeur. Gadamer.

\begin{abstract}
Metaphysics belongs to the backbone of the philosophical tradition. However, the term, often still cause some sort of discomfort in academic circles. Here we initially propose to show that, in fact, a particular model of metaphysics sank. Secondly, we will justify the resumption of the debate on metaphysics through anthropological reasons and hermeneutic phenomenology tradition, emphasizing French and German perspectives. Finally, we will argue on the metaphysics issue that must incorporate temporality within its own discourse. We have found striking indications in Ricoeur's works, within hermeneutic phenomenology tradition, which allows us to reconfigure in a new and suitable style the narrative metaphysics that integrates understanding and conception of person in its core.
\end{abstract}

Keywords: Metaphysics. Hermeneutics. Time. Person. Ricoeur. Gadamer.

* Possui graduação em Filosofia pela Universidade Federal de Minas Gerais - UFMG (1990), mestrado em Filosofia pela Pontifícia Universidade Católica do Rio Grande do Sul (1994), doutorado em Filosofia pela Pontifícia Universidade Católica do Rio Grande do Sul (2000) [doutorado Sanduíche pela Universidade de Heidelberg], pós-doutorado em Filosofia pelo Boston College - EUA (2006). Atualmente é Professor Titular I da Universidade do Vale do Rio dos Sinos e Bolsista PQ2 do CNPq. Tem experiência na área de Filosofia, com ênfase em Filosofia da Linguagem, Metafísica, Ontologia, Fenomenologia, Hermenêutica, Filosofia Antiga, atuando principalmente nos seguintes temas: hermenêutica filosófica e metodológica, linguagem, jogo, dialética.

\begin{tabular}{|l|l|l|l|l|l|}
\hline Veritas & Porto Alegre & v. 58 & n. 2 & maio/ago. 2013 & p. 308-332 \\
\hline
\end{tabular}


De facto, estou demasiado afastado desse tipo de metafísica. Mas, a minha maior preocupação nunca foi a de saber se e como poderia eu sobreviver à desconstrução da 'própria' metafísica. Pelo contrário, ela tem sido a de fazer metafísica de uma outra maneira, na base precisamente, da fenomenologia hermenêutica. ${ }^{1}$

O Eu sou tem de se alcançar pela via dum trabalho de interpretação: 'a autoposição não é um dado, mas sim uma tarefa'. ${ }^{2}$

O termo metafísica ainda causa uma espécie de estarrecimento e mal-estar no meio acadêmico por inúmeros fatores de ordem teórica e supostos desdobramentos práticos. Nosso propósito, aqui, é retratar, inicialmente, algumas críticas desferidas contra a metafísica e assinalar seus equívocos e acertos com o escopo de apontar que um determinado modelo metafísico soçobrou. A seguir, mostraremos a necessidade de refletirmos, hoje, sobre a metafísica por razões antropológicas e por razões contidas na tradição fenomenológico-hermenêutica. Ao final, retomaremos Ricoeur, em quem encontramos argumentos próprios da tradição fenomenológico-hermenêutica que nos permitem reconfigurar, num estilo novo e apropriado, a metafísica que integra o conceito de temporalidade, de pessoa, de modo a instituir o que designamos de metafísica narrativa.

\section{Situação: limitações e perspectivas para a metafísica}

Atualmente, ainda parece de bom tom falar mal da metafísica! Isto tornou-se tão comum que, para ofender alguém ou desmerecer seu discurso, basta adjetivá-lo de metafísico. Vivemos como se ela tivesse morrido ou como se vivêssemos em tempos pós-metafísicos ou como se fosse um tema démodé ou se tratasse de um discurso metaempírico. Ao examinarmos o itinerário da metafísica, percebemos que, desde Nietzsche, Kierkegaard e Comte, "iniciou-se o abandono do espaço secularmente ocupado, ao menos desde Sócrates-Platão e Aristóteles, pelo pensamento metafísico, e toda a filosofia contemporânea concorda

1 RICOEUR, P. Resposta a G. B. Madison. In: HAHN, L. E. (Org.). A filosofia de Paul Ricoeur. Lisboa: Instituto Piaget, 1997, p. 65.

2 SUMARES, M. O sujeito e a cultura na filosofia de Paul Ricoeur. Lisboa: Escher, 1989, p. 163-164 (grifos nossos). 
na necessidade de abrir brechas em outra direção, e de dar por esgotado e concluído o reino da metafísica". ${ }^{3}$

Qual metafísica morreu? ${ }^{4}$ Soçobrou e deve ser superado um modelo de metafísica estruturado sobre o "racionalismo dogmático e não humano, que crê poder engendrar e apreender o todo da realidade pelo jogo de uma necessidade rigorosa" ${ }^{5}$ cujo escopo consiste em constituir um sistema de princípios pré-estabelecidos e oferecer um mundo absolutamente seguro que eliminaria "o movimento da existência finita" e arrancar-nos-ia "de nossa condição sempre frágil e sempre relativa". ${ }^{6}$

$\mathrm{Na}$ raiz dos projetos metafísicos com tais matizes, encontra-se a dificuldade de lidar e suportar a instabilidade da existência fenomenal, a finitude, isto é, seu caráter temporal. Os conceitos construídos sobre essa dificuldade levaram à elaboração de sistemas conceituais que "se parecem a gaiolas gigantescas ou a cemitérios gigantescos; pois elas se esforçam na verdade em fixar em um saber de morte o movimento e a variedade do mundo e da existência". ${ }^{7}$

Sabemos que Heidegger foi um crítico mordaz da metafísica da presença que, para ele, caracteriza a história da metafísica ocidental: "o fundamental é então a noção de finitude do Dasein, o que a metafísica 'esqueceu'. Para Heidegger a história da metafísica pensou o ser como a-temporal, sem devir, o que acaba por conduzir ao esquecimento do ser". ${ }^{8}$ Nessa direção, para Ricoeur, "mais do que opor uma ontologia do acto a uma ontologia da substância, o fundamental é antes repensar o substancialismo da tradição que, ao dar um peso excessivo à ousia, obliterou a relação enérgeia-dinamis". ${ }^{9}$ Em entrevista a Fabrízio, Ricoeur reiterou isso: "a metafísica ocidental preferiu ser como substância a ser

3 TRÍAS, Eugenio. La superación de la metafísica y el pensamiento del límite. In: VATTIMO, G. La secularización de la filosofía. Barcelona: Gedisa, 1994, p. 283.

4 Ver mais detalhes sobre esta questão em ROHDEN, L. Morreu a metafísica? Reflexões críticas e o louvor à metafísica. In: CIRNE-LIMA, C.; HELFER, I.; ROHDEN, L. Dialética, caos e complexidade. São Leopoldo: Editora Unisinos, 2004, p. 209-244.

5 GUIBAL, F. "La métaphysique en question", Études, 351 (1979), p. 186.

6 Ibidem, p. 186.

7 Ibidem, p. 188.

8 HELENO, J. M. M. Hermenêutica e ontologia em Paul Ricoeur. Lisboa: Instituto Piaget, 2001, p. 213. E ainda de acordo com ele, "Grondin escreve significativamente: 'a metafísica escamoteia o futuro autêntico do Dasein abandonando-se à hegemonia inautêntica, mas reconfortante do presente. Isto explica porque é que o ser será metafisicamente compreendido na órbita da presença, da permanência na presença'. Ibidem, p. 43. Ora o que pode dar sentido à pergunta que interroga pelo sentido do ser é o tempo. Ser e tempo - isto é, a pergunta pelo sentido do ser tem o tempo como resposta (exatamente como perguntar pelo sentido do tempo é ter como resposta a narrativa, para parafrasear o título da obra de Ricoeur). A dialética da pergunta e da resposta mostra então o parentesco que une as obras de Heidegger e de Ricoeur citadas". Ibidem, p. 213.

9 Ibidem, p. 353. 
como ato e potência. Se a gente identifica a metafísica ao substancialismo, sim, então eu estou do outro lado, mas isto não quer dizer que não há uma outra metafísica possível". ${ }^{10} \mathrm{E}$, ainda, Ricoeur justifica sua crítica à metafísica substancialista, perguntando: "a teoria da substância não tende, desde então, a amortecer o benefício da distinção entre duas significações primitivas do ser, ou segundo as categorias e do ser como potência e ato?"11 Na esteira da tradição fenomenológica francesa e alemã, de acordo com Ricoeur, o ocidente absolutizou a metafísica enquanto ser categorial e olvidou o ser como ato e potência; ${ }^{12}$ do ponto de vista da tradição platônica, na qual encontramos uma ontologia de primeiro e de segundo grau, a primeira atém-se à definição dos seres e a outra constitui-se enquanto exercício de interrogação pelo próprio ser. ${ }^{13}$

Os sistemas metafísicos perdem sua razão de ser à medida que não incorporam o tempo e os seus atributos na sua rede conceitual, isto é, quando não incluem, no seu discurso, a explicitação conceitual da identidade humana e abordam o real com métodos que não são coerentes e correspondentes com seu modo de ser. Eis o paradoxal círculo vicioso no qual a boa parte da humanidade encontra-se enredada, ou seja, de "conhecer para desconhecer" ${ }^{14}$ quem somos. Ora, a matriz dessa circularidade viciosa alimentou e sustentou um discurso metafísico abstrato que levou e leva-nos ao afastamento gradual e sistemático em termos de conhecimento e de cuidado de nós mesmos.

Morreu, pois, a metafísica que não soube dar conta do seu objeto essencial, da pessoa essencialmente móvel em sua constituição e explicitação conceitual, ou seja, que não soube integrar a temporalidade no

10 TUROLDO, F. Verità del Metodo. Padova: Il Poligrafo, 2000, p. 253-254 (grifos nossos).

11 RICOEUR, P., AS, p. 354 ap. HELENO, J. M. M., op. Cit., p. 353.

12 "Entre as quatro acepções do ser [...] Ricoeur privilegia o par energeia-dynamis, a fim de elucidar os pressupostos ontológicos da sua hermenêutica do si". Ibidem, p. 187.

13 "Ricoeur considera que há dois níveis ontológicos na filosofia de Platão: "há uma ontologia de primeiro grau, que se atém à definição dos seres e que procura determiná-los, e há, também, uma ontologia de segundo grau, que interroga pelo próprio ser"; ou seja, Platão foi crítico de si mesmo: "contudo será no Sofista que retomará as aporias do Parmênides desenvolvendo a 'ontologia de segundo grau' assentada não já na relação Uno-Múltiplo mas sim na questão dos 'grandes gêneros', isto é, na dialética entre ser e não ser, entre o Mesmo e o Outro, o Movimento e o Repouso". HELENO, op. cit., p. 323.

14 Prova disso é a produção crescente de inúmeros saberes úteis e necessários à vida humana que são sustentados, contudo, por uma intencionalidade reducionista, na medida em que "acabam por obscurecer o foco luminoso da própria essência do conhecimento, do qual irradia a sua irredutível originalidade humana e no qual se revela a mais profunda e como que abissal experiência que nos é dado fazer da nossa identidade: a de conhecermos a nós mesmos e a realidade que se abre diante de nós". VAZ, C. H. L. "Tópicos para uma metafísica do conhecimento". In: ULLMANN, R. A. (Org.). Consecratio Mundi. Porto Alegre: Edipucrs, 1998, p. 437. 
seu discurso. O sentido do ser efetiva-se e compreende-se temporalmente. Porém, se fracassou um modelo de metafísica [substancialista, dogmática, fechada, da presença], não podemos deduzir disso que a metafísica tenha sido ou deva ser extirpada da filosofia. Ricoeur mesmo, apesar de evitar o uso do termo metafísica e preferir empregar ontologia, confessou que houve uma evolução no seu pensamento. Ele diz que, na sua primeira fase, "era antimetafísico", mas que deixou de sê-lo e, inclusive, afirmou: "eu me permito dizer que sempre fui favorável por uma metafísica do ato, do ser como ato". ${ }^{15}$

Vimos que a tentativa de erradicar a metafísica do bojo da filosofia não se sustenta porque parte de um equívoco; ao levar em conta um modelo metafísico [substancialista, sistemático fechado], deduziu-se que a metafísica como um todo morreu. Vejamos argumentos antropológicos [ou existenciais] e razões encontradas na tradição fenomenológicohermenêutica para levar a sério a metafísica na perspectiva de reelaborá-la.

\section{Razões antropológicas e hermenêuticas para retomar a metafísica}

A metafísica não se desfaz como se desfaz uma opinião. Não se pode deixá-la para trás como se faz com uma doutrina em que não mais se acredita ou defende. ${ }^{16}$

Antes de apresentarmos uma outra metafísica tecida com o fio da temporalidade, vejamos dados que nos revelam que há uma metafísica em ato, presente no ato de conhecer e de ínsito ao ser humano. Ao lado disso, desvendamos, na tradição fenomenológica e hermenêutica, uma metafísica implícita ao dedicar-se à compreensão e à instauração do sentido do ser.

\subsection{Argumentos de caráter fenomenológico-antropológico}

Talvez seja em Aristóteles que encontramos a melhor expressão do homem enquanto animal metafísico em sua formulação: "todos os homens, por natureza, tendem ao saber". ${ }^{17}$ Saciar ou não essa sua sede de saber depende de vários fatores, e quem negar ou recusar efetivar essa condição antropológica assemelhar-se-á a uma planta. De acordo com B. Russel, um dos três motivos que fazem com que uma vida valha

15 TUROLDO, op. cit., p. 256 e p. 253.

${ }^{16}$ HEIDEGGER, M. Ensaios e conferências. 2. ed. Petrópolis, RJ: Vozes, 2001, p. 61.

17 ARISTÓTELES, Metafísica, I, 1, 980a. 
a pena ser vivida é justamente "a procura do saber", ${ }^{18}$ o que constitui um exercício metafísico.

O ser humano é um animal metafísico, e a metafísica pertence à sua natureza, à medida que ele não se satisfaz apenas com pão, pois seu modo mais próprio e autêntico de ser é ex-sistir ${ }^{19}$ por criar e nutrir-se de ideias, de utopias, de esperanças ou desesperanças. A dimensão meta[física] ${ }^{20}$ é um dado do seu ser e compõe sua natureza, visto que ele não está aí apenas enquanto pura sistência, mas pode sair e voltar a si enquanto ex-sistência. Enquanto ser, ele efetiva-se no tempo e enquanto tempo; mais que simples dado, ele é ato-potência.

De acordo com Heidegger, o traço metafísico do homem revela-se no seu gesto incessante de perguntar, no qual estamos implicados, pela totalidade que rompe os limites da imediatidade de modo que "a metafísica é uma interrogação na qual nos inserimos de modo questionador na totalidade e perguntamos de uma tal maneira que, na questão, nós mesmos, os questionadores, somos colocados em questão". ${ }^{21}$ No conhecimento e pelo exercício metafísico não apenas rompemos os horizontes do real, como nos conhecemos mais e melhor, porque, nele, estamos envolvidos tanto ao longo quanto ao final do seu processo. $O$ saber metafísico é sempre um saber autoimplicativo, irredutível à lógica do conhecimento linear de causa e efeito que tende a prescindir, ao longo prazo, do tempo e dos seus atributos. A interrogação metafísica, que nos qualifica enquanto pessoas, é motivada [ao mesmo tempo em que nos move] por nossa ânsia para compreender o sentido e pelo impulso para explicitar a totalidade do [nosso] ser e do mundo.

Em E. Lévinas, o desejo é um traço constitutivo e revelador da constituição metafísica do ser humano, pois ele é e expressa "uma experiência radical de alteridade", o que situa sua reflexão "em um horizonte teórico original e irredutível ao prevalecente 'teoreticismo' da metafísica tradicional", uma vez que, nele, "existe um componente metafísico que o faz irredutível à necessidade, ou inclusive à paixão; o desejo não se satisfaz como a fome ou o impulso sexual" compreendido em sua afirmação "o desejo metafísico tende em direção a uma coisa totalmente outra, rumo ao absolutamente outro". ${ }^{22} \mathrm{O}$ desejo ínsito

18 RUSSEL, B. Memórias apud BODIL, J. Dez considerações sobre o tempo. Rio de Janeiro: José Olympio, 2004, p. 94.

19 HEIDEGGER, op. cit., p. 63.

20 Traduzível por racional, espiritual ou simplesmente filosófico.

${ }^{21}$ HEIDEGGER, op. cit., p. 11.

22 VATTIMO, G. "Metafísica, violencia, secularización". In: VATTIMO, G. (Comp.). La secularización de la Filosofía. Hermenéutica y posmodernidad. Barcelona: Gedisa, 1994, p. 77. 
ao homem leva-o a sair da sua situação imediata para uma região que lhe é desconhecida, portanto, metafísica, não para efetivar uma fuga mundi, mas para realizar-se plenamente. Abraão representa, paradigmaticamente, este movimento metafísico de saída de sua terra motivado pelo desejo de conhecer e de conviver com o outro, o novo, o diferente dele e de sua terra. Esse movimento não é metaempírico pura e simplesmente, uma vez que há uma saída de si e uma volta a si mesmo que redunda num alargamento da consciência, bem como da atuação no mundo. Analogamente, a realização do desejo pode ser equiparada à experiência realizada pelas pessoas que assistiam às tragédias gregas que, ao saírem de si mesmas e envolverem-se com os dramas representados pelos personagens, retornavam a si mesmas engrandecidas pela ampliação de sua visão de mundo e por uma ação de alcance mais universal. O desejo conduz ao rompimento dos limites do horizonte empírico e da tendência à inércia que ronda as pessoas e negá-lo ou não o efetivar implica escamotear seu modo [metafísico] de ser.

Entre os poucos filósofos contemporâneos que não entoaram os cantos fúnebres à morte da metafísica e procuraram distingui-la do discurso da ciência está M. M. Ponty, para quem, no próprio processo de pensar e de conhecer, encontra-se e revela uma metafísica em ato. Para ele, a metafísica não cessou de levar uma vida clandestina na poesia, na literatura e, inclusive, nas ciências como a linguística, a sociologia e a historiografia. Ele defende uma concepção diferente de metafísica, na medida em que justifica um modo de conhecer e de pensar que não parte nem se sustenta na cisão radical e excludente entre sujeito e objeto. $\mathrm{Na}$ metafísica em ato, latente no ocidente, o sujeito não possui a pretensão controladora de decompor os objetos, os quais, por sua vez, não são reduzidos a entidades ou a fatos empíricos.

Foi nas reflexões sobre linguística que Ponty encontrou e elaborou argumentos para sustentar o que ele chamou de metafísica em ato. Tais reflexões revelaram o fracasso das tentativas de estudar a língua segundo métodos científicos que descartaram "as concepções pré-científicas ou animistas que representavam cada língua como um organismo ou como um ser de razão cuja evolução apenas manifestaria, pouco a pouco, a essência invariável"; em suma, a língua não se reduz a uma coisa cuja descoberta de suas leis poderia revelar seu funcionamento. ${ }^{23} \mathrm{O}$ real e, no caso, a linguagem, não podem ser concebidos nem construídos segundo a lógica do procedimento científico-positivista. Essa descoberta levou-o a sustentar a vigência de uma metafísica em ato, o que indica

${ }^{23}$ MERLEAU-PONTY, M. O metafísico no homem. São Paulo: Abril Cultural, 1980. (Os pensadores), p. 181. 
uma metafísica latente no ocidente calcada sobre uma concepção mais ampla, tanto do objeto investigado, quanto da postura de abertura do sujeito relativamente a ele.

A busca de compreensão do sentido e do significado dificilmente "é solucionável através de uma definição de palavras que obteríamos através do estudo da linguagem", pois os próprios linguistas nos ensinam que

[...] a significação unívoca é apenas uma parte da significação da palavra, que há sempre, além, uma auréola de significação que se manifesta em modos de emprego novos e inesperados [...] longe de deter o segredo do ser do mundo, a linguagem é, ela mesma, um mundo, ela mesma, um ser [...] fala do ser e do mundo, redobrando, pois, seu enigma, em vez de fazê-lo desaparecer. ${ }^{24}$

A metafísica em ato pressupõe um sujeito para quem "há certas imagens que não podemos dispensar. Exigir que usemos apenas termos correspondentes às realidades da linguagem é pretender que tais realidades não mais tenham mistérios para nós". ${ }^{25}$ Com isso, Ponty apontou para uma concepção de real mais ampla que aquele construído pelas ciências exatas e mostrou-nos que o mistério, o metafísico, o espírito, o sentido de uma língua não cabem dentro de suas letras nem se confinam em conceitos.

Visto assim, parece que somos condenados não apenas a assumir nossa condição metafísica, mas a atualizá-la para vivermos de modo autêntico e pleno. A proclamação do fim da metafísica implica a morte da própria filosofia e das construções conceituais possíveis acerca do nosso modo próprio de ser. As críticas desferidas contra a metafísica, na verdade, dirigem-se ao modo de fazê-la ou concebê-la. A atualização do traço antropológico-metafísico jamais levará ao esgotamento de todas as possibilidades de ser do Ser [pessoa]. O equívoco cometido por aqueles que proclamaram o fim da metafísica nasceu do engodo de pensar que o discurso metafísico, uma vez sistematizado, consistiria apenas em deduzir o real; seu pressuposto teórico expulsou a temporalidade, levou à justificação de sistemas totalitários e à eliminação da própria pessoa do seu bojo conceitual. Contudo, se algo caracteriza o ser humano, é justamente a ânsia insaciável de querer compreender o real, de querer

${ }^{24}$ MERLEAU-PONTY, M. O visível e o invisível. São Paulo: Perspectiva, 2003, p. 97-98.

25 MERLEAU-PONTY, M. O metafísico no homem. São Paulo: Abril Cultural, 1980. (Os pensadores), p. 182. Esta noção de "metafísica em ato" tematizada por Ponty possui várias analogias com a concepção de ontologia da linguagem desenvolvida por Gadamer, para quem "o que está em questão não é o que nós fazemos, o que nós deveríamos fazer, mas o que, ultrapassando nosso querer e fazer, nos sobrevém, ou nos acontece". GADAMER, H-G. Verdade e Método I. Petrópolis, RJ: Vozes, 1997, p. 14. 
nomear aquilo que deseja, de pretender palavrear aquilo que procura, enfim, de explicitar o sentido - em todos os tempos e lugares - e que não pode ser circunscrito num sistema conceitual abstrato, absoluto e fechado.

Disso segue-se que podemos erigir uma outra trama conceitual, metafísica, com contornos próprios. Essa outra perspectiva escava sempre novas respostas às diferentes questões e problemas e, se não se satisfaz com elas, não é porque não possuam validade própria, e sim porque não as toma como definitivas ou absolutas pela simples razão que o ser humano é um pro-jeto de ser pessoa, uma tarefa a ser realizada entre os limites de ato e potência, daí porque "viver - ...-é muito perigoso. Porque ainda não se sabe. Porque aprender-a-viver é que é viver, mesmo". ${ }^{26}$ A procura pelo que é o correto, o justo, o bem, o essencial, o viver, constituição de uma efetivação do nosso modo metafísico de ser que implica a elaboração de uma linguagem metafísica que anseia pela explicitação mais apropriada [do sentido] do ser. Ora, é na tradição fenomenológica e hermenêutica que encontramos explicitado o sentido do sentido do ser [do real, dos textos, da vida] que compõe uma rede conceitual própria que, mesmo que não tenha sido nomeada de metafísica, concebemo-la como uma metafísica em ato ou narrativa na esteira de Ricoeur.

\subsection{Argumentos fenomenológico-hermenêuticos ${ }^{27}$ ou sobre o sentido do(e) Ser}

Não é por acaso que, no mesmo tempo em que as vozes proclamando a destruição da metafísica avolumaram-se - levando à criação de um clima antimetafísico generalizado -, pudemos presenciar a emergência e a desenvoltura da tradição fenomenológica e hermenêutica no itinerário da filosofia ocidental. Já para Dilthey, "a vida devia ser compreendida a partir da experiência da própria vida" que havia constatado e denunciado o fato de que "nas veias do sujeito cognoscente [...] não corre verdadeiro sangue". ${ }^{28}$ Para ele, "a vida é o elemento ou fato básico (Grundtatsache) que deve constituir o ponto de partida para a filosofia [...] é aquilo que não podemos ultrapassar", ${ }^{29}$ isto é, não pode ser reduzida a uma construção abstrata. Mesmo que a solução hermenêutica de Dilthey tenha

${ }^{26}$ ROSA, J. G. Grande Sertão: Veredas. 2. ed. Rio de Janeiro: José Olympio Editora, 1958, p. 550.

27 Poderíamos dizer que se tratam de argumentos de ordem existencialista, também; contudo, não o fizemos dada a amplitude que se abriria e limitação de tempo e espaço de escritura para tal. Por isso, para nosso propósito, levamos em conta Heidegger, Gadamer e Ricoeur.

28 PALMER, R. Hermenêutica. Lisboa: Edições 70, 1997, p. 109.

29 Ibid., p. 126. 
permanecido atrelada ainda ao idealismo objetivo, seu projeto sustenta outra forma de pensar e de conhecer que reivindica a integração e a conservação do valor e do sentido da vida humana no discurso filosófico. Essa indicação estenderá suas raízes, na forma da facticidade ou temporalidade, na tradição hermenêutica posterior. Em outras palavras, partimos da hipótese de que a tradição fenomenológico-hermenêutica apresenta-nos uma metafísica, ainda que implícita - e que precisa ser explicitada e escrita de forma apropriada,$-{ }^{30}$ visto que ela está às voltas com uma compreensão discursiva universal do real tecida com o fio da temporalidade estampada no seu esforço de compreender e de instaurar o sentido [de e do Ser]. É na tradição hermenêutica desenvolvida por Heidegger, Gadamer e Ricoeur ${ }^{31}$ que encontramos distintos caminhos e a metacompreensão do ser enquanto instauração do sentido. Com isso, eles ofereceram-nos ótimos argumentos que sustentam a retomada e a elaboração de uma metafísica tecida com o fio da temporalidade. Por diferentes vias, elaboraram um discurso filosófico sobre a compreensão do homem enquanto construção pessoal, isto é, temporal. Nossa hipótese é de que a tradição fenomenológico-hermenêutica passou a ocupar, num certo sentido, o espaço próprio ocupado pela metafísica ocidental, ou pelo menos reivindicou que se recolocasse o tempo e a construção da identidade humana no foco das discussões e das construções filosóficas. Não se conclui disso que a hermenêutica seja, hoje, o avesso autêntico da metafísica de ontem, todavia, acentua-se apenas o fato de que o tema da pessoa - implícita e explicitamente - ocupa o centro e constitui o horizonte central do seu interesse e da sua explicitação conceitual.

De acordo com Heidegger, "o problema ontológico fundamental, da exegese do ser enquanto tal, abarca por fim o manifestar da temporalidade do ser. Na exposição dos problemas da temporalidade, dá-se pela primeira vez a resposta concreta à pergunta que interroga pelo sentido do ser". ${ }^{32}$ Há, pois, uma ilação ontológica entre ser e tempo o que se realiza na instauração do sentido [do e de ser], ou seja, o tempo é, assim,

[...] o intervalo entre o que o ente é no presente e o que ele pode vir a ser - uma pura diferença, que se distende e constitui no decurso da ação e segundo o ritmo da sua efetivação. Síntese de ato e de potência, de determinação e indeterminação, é a estrutura inteira do ente em devir,

30 Este tem sido o principal foco das minhas pesquisas nos últimos anos.

31 De acordo com Madison - com quem concordamos plenamente - "é exatamente por a [não seria "pela"?] filosofia de P. Ricoeur ter sido orientada, do princípio ao fim, pelo conceito de sentido que ela é, na acepção mais correta do termo, fenomenológica". MADISON, G. B. In: HAHN, op. cit., p. 41.

32 HEIDEGGER, M. Sein und Zeit. Frankfurt: Vittorio Klostermann, 1977, p. 26 apud HELENO, op. cit., p. 363. 
que está sujeita à alteração, segundo um dinamismo nunca terminado de progressiva determinação da ação. Esta está orientada vectorialmente e faz-se regular e ordenamente, segundo fases sucessivas, que nunca são intermutáveis: o passado age sobre o presente, e no momento actual, o sujeito projeta as linhas da sua ação futura. ${ }^{33}$

Ricoeur leva adiante tal proposta, pois um dos seus principais pressupostos "é, precisamente, a forma como nos tem permitido repensar essa antiga e crucial questão da filosofia que somos nós próprios, a questão de saber o que é que significa ser um sujeito pensante, reflexivo" ${ }^{34}$ Pode-se afirmar que "as duas noções fundamentais presentes na metodologia ricoeuriana são a de sentido e a de existência. O objetivo a que ele se propôs constitui exatamente o mesmo da filosofia, tal qual Ricoeur a vê: "clarificar a própria existência através da utilização de conceitos'", ${ }^{35}$ o que configura a noção de sentido.

A noção de sentido resume as razões para retomar-se e reconfigurar a metafísica hoje. Que é o filosofar - ou então, o desejo e o anseio metafísicos que nos constitui - senão o esforço incessante de compreender e de explicitar o sentido para ser e vivermos mais felizes? A pergunta metafísica sobre nossa identidade, "a questão do sentido - o da existência, da vida, dos comportamentos - é levantada por todas as crianças em idade de se interrogarem e de interrogarem os seus pais: [...] que se passa quando morremos?" de modo que "o metafísico nasce na idade em que começamos a levantar questões". ${ }^{36} \mathrm{O}$ ato de perguntar tem por escopo elucidar o sentido do real. O sentido, enquanto "o primeiro nome do ser", ${ }^{37}$ não se esgota nas respostas relativas a ele tecidas ao longo da história. A metafísica, enquanto compreensão e explicitação sobre o sentido, "- enquanto interrogação fundamental - começa onde todos os saberes estabelecidos acabam", diferentemente do discurso da ciência que "constrói-se, desenvolve-se e enriquece-se por meio de um saber comunitário, admitido ou refutado, de uma forma mais ou menos universal". ${ }^{38}$ A interrogação metafísica alimenta-se dela mesma e não se satisfaz com respostas definitivas e absolutas, de modo que o discurso

33 BLANC, M. de F., Introdução à Ontologia. Lisboa: Instituto Piaget, s/d., p. 137-138.

34 MADISON, op. cit., p. 39. Em resposta ao texto de Madison, Ricoeur faz duas afirmações que corroboram nossa proposta aqui: “... uma vez que é de facto o destino da subjetividade humana que está em causa ao longo de minha obra". RICOEUR, P. "Resposta a G. B. Madison". In: HAHN, op. cit., p. 63.

${ }^{35}$ MADISON, op. cit., p. 40.

${ }^{36}$ NAYLA, F. A metafísica. Lisboa: Instituto Piaget, 1995, p. 8.

37 BORNHEIM, G. Dialética: teoria e práxis; Ensaio para uma crítica da fundamentação ontológica da dialética. Porto Alegre, Globo; São Paulo: Ed. da Universidade de São Paulo, 1983, p. 27.

38 NAYLA, op. cit., p. 9-10. 
metafísico correlativo será aberto, marcado pelo tempo. Além disso, "toda questão, até mesmo a que diz respeito ao simples conhecimento, faz parte da questão central que somos nós mesmos, deste apelo à totalidade ao qual nenhum ser objetivo dá resposta" ${ }^{39}$ definitiva e absoluta.

Na língua alemã, os termos sinnan, sinnen, "pensar o sentido, diz encaminhar na direção que uma causa já tomou por si mesma. Entregar-se ao sentido é a essência do pensamento que pensa o sentido. Este significa mais do que simples consciência de alguma coisa. [...] é a serenidade em face do que é digno de ser questionado". ${ }^{40}$ Nessa perspectiva, as perguntas pelo ser e pelo sentido [do real, da vida] convertem-se, porque estão às voltas com uma dimensão que vai além das questões rasas da vida. Diferentemente dos procedimentos da ciência, "no pensamento do sentido, encaminhamo-nos para um lugar onde se abre, então, o espaço que atravessa e percorre tudo que fazemos ou deixamos de fazer", e, por essa razão, o pensamento do sentido "nos põe a caminho do lugar de nossa morada". ${ }^{41}$ Esta procura pela compreensão e pela explicitação do todo, manifestada na pergunta pelo "que é o ser e o que é o nada?", configuram em primeira e última instância a busca pelo sentido [do real, da vida]. A partir disso, estamos apontando para uma noção de metafísica movente, uma vez que o pensamento e a explicitação do sentido têm um tom provisório, pois "os caminhos do pensamento do sentido sempre se transformam, ora de acordo com o lugar, onde começa a caminhada, ora consoante o trecho percorrido pela caminhada, ora conforme o horizonte que, no caminhar, vai se abrindo no que é digno de ser questionado". ${ }^{42}$ A pergunta o que é metafísica? [ou o que é o sentido?] fundamenta-se e alimenta-se com a pergunta acerca do nosso modo de ser no mundo. Encontrar e atribuir motivações e razões de ser no tempo que somos configura o sentido metafísico.

Retomar e reconfigurar tanto a concepção quanto a confecção de metafísica, hoje, significa, na verdade, recordar o fato filosófico de que somos "seres metafísicos", sedentos de compreensão do sentido do real. Desse modo, metafísica não é metaempiria, mas - enquanto incessante procura de compreensão e de explicitação do sentido - o movimento do pensar que salta para além da imediatidade e retorna a ela com uma consciência mais expandida. Salto que sempre será limitado por sermos

39 MERLEAU-PONTY, M. O visível e o invisível. São Paulo: Perspectiva, 2003, p. 104.

40 HEIDEGGER, op. cit., p. 58.

${ }^{41}$ Ibidem, p. 58.

42 Ibidem. Dito de outro modo, "o pensamento metafísico é o pensamento que se movimenta no cerne do conceito nesse duplo sentido: indo até a totalidade e transpassando conceptivamente a existência". HEIDEGGER, M. Os Conceitos Fundamentais da Metafísica. Rio de Janeiro: Forense Universitária, 2003, p. 12. 
seres temporais, situados no espaço, mas, nem por isso, totalmente determinados por ele. A retomada e a reconfiguração da metafísica, hoje, sob essa perspectiva hermenêutica convertem-se numa espécie de imperativo, pois a renúncia à condição humana de interrogar-se pelo sentido, pessoal e do real, implica o retorno ao estágio vegetal ou apenas animal.

Uma das limitações da metafísica ocidental residiu nas determinações que ela atribuiu ao indivíduo ao ser que eram, "antes de mais nada, as qualificações de sujeito e objeto, que constituíram o quadro em que se consolidou a própria noção de realidade". Ora, "perdendo "essas determinações" - e esta é a nossa hipótese também -,

o homem e o ser entram num âmbito schwingend, oscilante, que [...] deve ser imaginado como o mundo de uma realidade 'aliviada', tornada mais leve porque menos nitidamente cindida entre o verdadeiro e a ficção, a informação, a imagem: o mundo da mediatização total da nossa experiência, no qual já nos encontramos em larga medida. É nesse mundo que a ontologia se torna efetivamente hermenêutica, e as noções metafísicas de sujeito e objeto, ou melhor, de realidade e de verdadefundamento, perdem peso. ${ }^{43}$

Mais que simples atualização do seu código genético, o ser humano constitui-se no tempo e enquanto tempo. O discurso metafísico sobre a metafísica em ato - que constitui uma ontologia fraca, relacional, ou em aberto - sobre o animal metafísico que somos não pode ser medido pela régua matemática, mas pela régua de chumbo, conforme nos mostrou o estagirita. Trata-se de uma racionalidade tecida mais pela probabilidade que pela apodicticidade e que inclui e conserva, na sua tessitura, a temporalidade e, portanto, a explicitação conceitual de um modo de ser enquanto projeto e não como um simples dado. Desse modo, o discurso metafísico a ser elaborado precisará assumir outro matiz: o narrativo.

A fim de reconfigurar a metafísica, hoje, precisamos recolocar, de modo proporcional, no ponto de partida e de chegada do discurso metafísico, o tempo e seus atributos. Como o ser humano torna-se pessoa no tempo, enquanto tempo, ele não é uma "coisa ou substância, mas uma atividade vivida de permanente autocriação e incessante renovação; porque a sua autoconstrução é um ato criador de síntese, uma conquista e realização de $\mathrm{si"} .{ }^{44} \mathrm{O}$ projeto de reconfigurar a metafísica, hoje, parte do pressuposto ineludível de costurar um discurso metafísico que conserve, do princípio ao fim, o tempo e a pessoa. Com esse foco de atenção, propusemo-nos

43 VATTIMO, G. O fim da modernidade. São Paulo: Martins Fontes, 1996, p. 189-190.

${ }^{44}$ BLANC, op. cit., p. 110. 
reler a tradição metafísica com o escopo de reconstruir um discurso metafísico que salvaguarde, nele, o lugar e a tarefa de ser pessoa em sua historicidade. É na tradição hermenêutica que encontramos excelentes argumentos para a constituição de uma metafísica movente tecida pela linguagem narrativa. Corrobora isso uma das afirmações de Ricoeur, em que afirma que se distancia da segurança e das garantias que a ontologia do ser-em-si próprio forneceria para o pensar:

De facto, estou demasiado afastado desse tipo de metafísica. Mas, a minha maior preocupação nunca foi a de saber se e como poderia eu sobreviver à desconstrução da 'própria' metafísica. Pelo contrário, ela tem sido a de fazer metafísica de uma outra maneira, na base precisamente, da fenomenologia hermenêutica. ${ }^{45}$

Embora Ricoeur não tenha desenvolvido, de modo sistemático, essa outra metafísica e tenha-a denominado de ontologia quebrada [brisée] ou emergente, nossa meta, aqui, é explicitar o que compreendemos por metafísica narrativa a partir da tradição fenomenológico-hermenêutica, concedendo ênfase especial à filosofia ricoeuriana.

\section{Por uma metafísica narrativa}

Conhece alguém as fronteiras de sua alma para dizer sou eu?

F. PESSOA

O principal pressuposto da metafísica narrativa é a assunção do tempo e da noção de pessoa em sua tessitura. Diferentemente da noção moderna de pessoa enquanto cogito e autoconsciência, ela retoma o sentido antigo de per-sona o qual, por sua vez, conjuga, no seu bojo, a diferença e a identidade, de modo que tal sentido "reconhece a mediação, o per, que nada é dado imediatamente ou presente aqui". ${ }^{46}$ Além disso, diferente dos termos “'ego' e 'self' que pertencem à metafísica da identidade, per-sona está encravado na metafísica do fluxo" 47 que denominamos de metafísica movente, isto é, narrativa.

\subsection{Do ponto de vista hermenêutico, temporal, dialógico}

De acordo com a tradição hermenêutica, o objeto da investigação sempre em questão, em última instância, é "o saber do homem sobre si

45 RICOEUR, P. "Resposta a G. B. Madison". In: HAHN, op. cit., p. 65.

46 CAPUTO, John D. Radical Hermeneutics: Repetition, Deconstruction, and the Hermeneutic Project. Bloomington and Indianapolis: Indiana University Press, 1987, p. 289.

47 Ibidem, p. 290. 
mesmo e sobre o mundo de suas criações, no qual se depositou este saber. Ao final de uma ciência deste tipo, se encontra, não só conhecimento, mas uma permanente elaboração do saber do homem em relação a si mesmo". ${ }^{48} \mathrm{Um}$ dos intuitos da hermenêutica gadameriana consiste justamente em "vincular unitariamente a ciência e o saber do homem, em relação a si mesmo, a fim de conseguir uma nova autocompreensão da humanidade", e, para isso, serve a filosofia sob a forma de hermenêutica - "como teoria e também, como práxis da arte de compreender e fazer falar o estranho e o que se fez estranho" -, isto é, assimilar "a exigência délfica 'conhece-te a ti mesmo'" e reconhecer que somos humanos e não deuses. ${ }^{49}$ Posto isso, as construções metafísicas não podem pretender possuir respostas definitivas e absolutas sobre o real, mas constituem propostas nas quais somos espelhados e espelhamo-nos e que nos levam a pensar, sempre de novo, sobre quem somos e como vivemos.

$\mathrm{Na}$ tradição hermenêutica contemporânea, é possível encontrar justificadas as imbricações entre tempo e constituição da pessoa, pois, para ela, toda compreensão filosófica é, "explícita ou implicitamente, compreensão de si mesmo através do desvio da compreensão do outro". ${ }^{50}$ Partindo do fato de que o tempo "é o veículo da narração, como é também o veículo da vida", podemos dizer que, "o que somos, nós o somos apenas no tempo e através dele". ${ }^{51}$ De acordo com a hipótese de Ricoeur:

A característica comum da experiência humana, aquela que é marcada, organizada e clarificada pelo fato de se narrar, sob todas as suas formas, é a sua característica temporal. Tudo o que é relatado ocorre no tempo, leva tempo, desenvolve-se temporariamente; e o que se desenvolve no tempo pode ser relatado. ${ }^{52}$

Por um lado, é porque temos tempo que podemos ser e só podemos ser porque somos tempo; ${ }^{53}$ por outro lado, "o homem não vive nem fora do tempo, nem fora do espaço. Tudo o que ele faz passa-se num lugar preciso, num tempo precioso. Como consequência, sua rede deve estar ligada ao tempo e ao espaço". ${ }^{54}$ Assim, toda construção conceitual - seja ela metafísica, ética, estética ou política - que pretender desvencilhar-se

48 GADAMER, H-G. "Acerca da disposição natural do homem para a filosofia". In: A razão na época da ciência. Rio de Janeiro: Tempo Brasileiro, 1983, p. 84.

49 GADAMER, op. cit., p. 86-7.

50 RICOEUR, P. O Conflito das Interpretações - Ensaios de Hermenêutica. Porto-Portugal: RÉS-Editora, 1988, p. 18 e p. 19.

51 MEYERHOFF, H. O tempo na literatura. São Paulo: McGraw do Brasil, 1976, p. 27.

52 RICOEUR, P. On Interpretation apud MADISON, op. cit., p. 55-56.

53 ROHDEN, L. "O tempo no tempo e na constituição da metafísica movente", Síntese, 33 (2006), p. 53-76.

54 BODIL, op. cit., p. 86. 
do tempo e do espaço, pela abstração, fracassará por abstrair não apenas o ambiente, como também seu objeto de reflexão. Embora não possamos falar da "existência em si" do tempo, ele não pode ser considerado uma categoria acidental da substância - como foi considerado e, dessa forma, subsumido no bojo da maior parte das construções metafísicas -, e sim "seu modo de ser essencial, pelo qual ela é, mais do que a simples atualidade do dado, uma potencialidade ainda não cumprida, que assume, no caso do sujeito racional, a compleição de uma tarefa a realizar e de um livre poder de ação". ${ }^{55}$ Porque é e tem tempo é que o ser humano pode ser e viver [sua liberdade] e assim pode tornar-se pessoa; mais que atualização, por assim dizer automática, de uma potência, ele é capaz de construir múltiplas possibilidades de ser historicamente.$^{56} \mathrm{O}$ tempo não pode ser tomado apenas como condição de possibilidade para a atualização de uma determinada potência. Ilustra isso a suposição proposta por André Comte-Sponville:

Considerem este passarinho voando e suprimam o tempo. Seu voo se paralisa? Admitamos. Ele cai? Não, já que não tem tempo de cair [...] Então ele fica ali, no ar, imóvel, como que suspenso em pleno voo? Também não, já que tampouco tem o tempo de permanecer [...]. Então o quê? Então nada: se vocês suprimirem o tempo, tudo para e nada permanece, nem a própria imobilidade. Não há mais passarinho, nem mesmo ausência de passarinho: não há mais há, já que não há mais presente. ${ }^{57}$

Desta suposição, tiramos a lição de que não há ser sem ou fora do tempo e que o tempo não apenas possibilita o ser tornar-se [ser], mas é um modo de ser do ser. Na contemporaneidade, a hermenêutica é a perspectiva filosófica que mais levou a sério isso em seu esforço conceitual para compreender e explicitar o real. De acordo com V. Vitiello é inegável o êxito da hermenêutica à medida que

[...] a hermenêutica tem feito valer contra a 'lógica' os direitos da narração. O saber narrativo histórico no sentido originário se aproxima das coisas e da vida precisamente na medida em que se distancia da verdade absoluta e eterna: se aproxima das coisas, que sempre são 'relativas' e à vida do homem, que transcorre no tempo. ${ }^{58}$

55 BLANC, M. F. Metafísica do Tempo. Lisboa: Instituto Piaget, s/d, p. 218.

56 Ou seja, "porque tem e é futuro, mais do que passado, cada momento da sua vida é-o de uma escolha, em que se decide e atualiza aquilo que há de ser, em função dos valores em que se encontra e que o condiciona como ter-sido. Desta feita, é interrogando o futuro à luz do passado e da pertença a uma tradição, que o homem vive a sua vida, desbravando o seu caminho, decidindo quem é, através de uma escolha ininterrompida, que sempre se traduz em invenção criadora de possibilidades singulares de existência". BLANC, op. cit., p. 218-219.

57 COMTE-SPONVILLE, A. O Ser-Tempo. São Paulo: Martins Fontes, 2000, p. 98-99.

58 VITIELLO, V. Racionalidad hermenéutica y topología de la historia. In: VATTIMO, G. Hermenéutica y racionalidad. Barcelona: Grupo Editorial Norma, 1994, p. 212 (grifos nossos). 
Heidegger, com a hermenêutica da facticidade; Gadamer, com seu conceito de Wirkungsgeschichte; Ricoeur, com sua proposta de discurso mediato, que articula tempo e narração, estão a justificar um discurso que se aproxima das coisas e da vida tecendo uma linguagem apropriada ao modo de ser do ser que se diz de muitas maneiras.

Esta ânsia de compreensão e de explicitação da totalidade do ser pessoal e do real - configura o que denominamos de sentido. Enquanto seres metafísicos, "somos impelidos, em nossa saudade da pátria, para o ser na totalidade" de modo que nos tornamos pessoas impulsionadas por esta razão e motivação; ser significa estar "a caminho desse na totalidade. Nós mesmos somos este 'a caminho', esta travessia, este nem um, nem outro [...] Se quisermos vir a ser o que somos, não podemos abandonar essa finitude ou nos iludirmos quanto a ela". ${ }^{59}$ Já mostramos que a insuportabilidade da finitude humana esteve na base da construção dos sistemas absolutos desvinculados do tempo e dos seus predicados. Um dos fios condutores centrais da filosofia de Ricoeur é justamente a "imagem de homo viator" - "reconhecível tanto na sua reflexão sobre o sujeito como na sua reflexão incidindo sobre o sócio-político" para quem "as problemáticas do sujeito e da cultura [...] não se resumem no desejo de querer algo de absolutamente estável e definitivo ou no desejo de certeza racional". ${ }^{60}$ Também para Gadamer, impõe-se a tarefa "de uma destruição da conceitualidade da metafísica", de maneira que "o único sentido aceitável da expressão 'linguagem metafísica'" é "a conceitualidade formada em sua história". ${ }^{61}$ Considerando tais premissas, sustentamos também que o discurso metafísico precisa possuir o rosto dos seus construtores. Não podemos construir uma metafísica que não seja condizente com nosso modo humano de ser. Ora, este ser metafísico, sempre a caminho, em travessia, pode ser explicitado apropriadamente de forma narrativa.

Gadamer oferece-nos excelentes indícios de uma metafísica tecida com o fio do tempo que integra a compreensão e a explicitação conceitual da pessoa em seu discurso. A relação não é nem de submissão nem de domínio, e sim de mútua implicação, pois "a consciência hermenêutica tem sua consumação não na certeza metodológica sobre si mesma, mas na pronta disposição à experiência que caracteriza o homem experimentado face ao que está preso dogmaticamente". ${ }^{62}$ A metafísica narrativa orienta-se pela estrutura da arte de dialogar. E esta assume a

59 HEIDEGGER, op. cit., p. 7.

60 SUMARES, op. cit., p. 283.

61 GADAMER, H-G. Verdade e Método II. Petrópolis, RJ: Vozes, 2002, p. 424.

${ }^{62}$ GADAMER, H-G. Verdade e Método I. Petrópolis, RJ: Vozes, 1997, p. 533. 
roupagem do saber prático, phronético, que, por sua vez, enraíza-se na práxis que vive da "'sabedoria' para a qual conta [...] mais que a exatidão, a intuição, a faculdade de distinguir o momento oportuno, o kairós; [...] a téchne política da mediação". ${ }^{63}$ É enquanto mediação - e não submissão ou domínio - linguística que o ser humano pode tornar-se pessoa plenamente. Mediar é um modo de mostrar que discerne e conserva, no discurso, o real com suas ambiguidades e potencialidades. A linguagem narrativa conserva isso em seu bojo ao articular linguisticamente o descrever, o prescrever, o projetar e o ponderar sobre diferentes possibilidades de[o] ser [de se viver]. Em linguagem ricoeuriana, nós não apenas nos compreendemos diante do espelho dos textos, como também nele projetamo-nos, refletimo-nos e constituímo-nos. Fazer metafísica não significa apenas re-ler o que já se disse sobre o modo de ser [pessoa], mas implica reavaliar incessantemente o processo de espelhamento, de projeção, de reflexão, de constituição da identidade humana na e enquanto linguagem. Um dos pressupostos fundamentais da linguagem narrativa é justamente a existência de alguém que retoma o que já se disse sobre algo e de alguém que esteja ouvindo ativamente o relato e dele extraindo suas conclusões pessoais, dialogicamente.

\subsection{Do ponto de vista da construção conceitual, narrativa}

Ricoeur, em sua obra, procurou "'redescobrir o lugar do homem no mundo, ou, por outro lado, recuperar a sua dimensão metafísica'". ${ }^{64}$ É nele que encontramos argumentos para compreender, explicitar e elaborar uma concepção de identidade humana, enquanto pessoa, em contraposição e correção da metafísica ocidental, porque "em vez de centrar-se no eu penso, eu vejo, isto é, no problema da representação da consciência especular", ele "acentua o eu quero, eu ajo, da vida prática e afetiva". ${ }^{65}$ Para ele, "a existência humana é como um diálogo com um involuntário múltiplo e proteiforme - motivos, resistências, situações irremediáveis - a que o querer responde por escolha, esforço, consentimento", ${ }^{66}$ o que impede a delimitação conceitual definitiva e absoluta do modo de ser [da pessoa] a uma de suas dimensões, seja mental ou corporal. Como se percebe, Ricoeur retém

[...] das investigações fenomenológicas a natureza perspectivista e finita de todas as nossas inquirições e, ao abandonar a posição do ego como o senhor da consciência que projeta o seu olhar soberano, prefere

63 VITIELLO, op. cit., p. 212-213 (grifos nossos).

${ }_{64}$ RICOEUR, P. Existencial Phenomenology apud SUMARES, op. cit., p. 29.

65 SUMARES, op. cit., p. 31.

${ }^{66}$ RICOEUR, P. Le volontaire et l'involontaire, p. 259 apud SUMARES, op. cit., p. 50. 
empenhar-se na esfera concreta do que ele denomina o 'eu posso', delimitando o campo prático da ação. O ego é reinscrito no interior da problemática da ação como um campo de potencialidades [...] o sujeito da ação, tal como o autor do discurso, não pode ser uma consciência imediata, transparente para ele próprio. ${ }^{67}$

Portanto, o conceito de pessoa não é um dado absoluto, mas uma tarefa e um processo de interpretação, uma vez que "o sujeito que se interpreta ao interpretar os signos já não é o cogito; é um existente, que descobre, pela exegese de sua vida, que está posto no ser mesmo antes de se pôr e de se possuir". ${ }^{68}$ Nessa perspectiva hermenêutica, a metafísica constitui-se enquanto um processo de explicitação conceitual que toma seu objeto como algo que necessita ser sempre incessantemente [re] interpretado o que é possível graças ao tempo e à linguagem.

A linguagem narrativa é apropriada a esse processo ontológico de descoberta e de explicitação da identidade pessoal, pois, além de tecer uma íntima relação entre abstração e práxis, conserva o que se diz sobre o modo de ser e assegura a possibilidade de dizer o que ainda não se disse. E ela conserva a tensão entre fenomenologia - ao recolher as experiências sobre os diferentes modos de ser pessoa - e hermenêutica - ao deixar em aberto outros modos possíveis de ser, já que este diz-se de diferentes maneiras nos diferentes tempos e lugares. A linguagem metafísica apodíctico-demonstrativa construída no ocidente esteve mais preocupada com aquilo que permanece aquém e acima da temporalidade, com o sub-stare no tempo. Já a linguagem hermenêutico-metafísica narrativa está às voltas com aquilo que subjaz no tempo enquanto tempo e, no caso, com o ser enquanto pessoa. O fato é que o ser humano,

[...] jamais feito ou acabado, nem tão pouco estabelecido, em contínuo sobressalto pelo tempo que, de surpresa, o consuma e recria, define-o a inquietude, o dinamismo, a itinerância, a incessante busca do seu fim, a referência ao valor por que há-de pautar a sua vida, não sossegando enquanto não der uma resposta ao apelo fundamental do ser, que se faz ouvir mais além, através dos apelos do mundo [...]. O homem vai-se, assim, determinando e cumprindo como pessoa, sem, todavia, se fechar à contínua interpelação do futuro, que faz do seu ser um ser em aberto. ${ }^{69}$

Ricoeur retomou e reformulou a concepção de sujeito "num quadro que ultrapassa a posição entre a exaltação cartesiana do sujeito e sua humilhação nietzschiana, entre o triunfalismo do cogito de Descartes

${ }_{67}$ BLAMEY, K. "Do ego ao si: um itinerário filosófico". In: HAHN, op. cit., p. 121.

68 RICOEUR, P. Existence et hermeneutique, p. 15 apud SUMARES, op. cit., p. 161-162.

69 BLANC, op. cit., p. 109. 
e o niilismo anticogito de Nietzsche". ${ }^{70}$ A identidade pessoal e sua explicitação não são puras ilusões nem são dados absolutos, mas são tecidos pela linguagem que contém sempre o selo da temporalidade. É na linguagem que "o sujeito advém como aquele que é capaz de designar-se a si mesmo como locutor, como sujeito falante, que é capaz de apropriarse do sentido de uma língua, de usar seus signos, para se designar a si mesmo". ${ }^{71}$ Ora, esta linguagem narrativa, metafísica - irredutível à sua face dedutiva ou instrumental - é constituinte e constituidora do real, intrinsecamente móvel e temporal.

Partindo do fato de que o tempo "é o veículo da narração, como é também o veículo da vida", podemos dizer que "o que somos, nós o somos apenas no tempo e através dele". ${ }^{72}$ Ricoeur procurou articular, entrelaçadamente, o tempo e a noção de identidade humana discursivamente; encontrou na narração histórica e "de ficção, o recurso adequado para enfrentar as aporias do tempo"73, pois "o tempo torna-se humano na medida em que é articulado sobre um modo narrativo e a narração alcança sua significação plena quando torna-se uma condição da existência temporal". ${ }^{74} \mathrm{Na}$ sua teoria narrativa, conservam-se a identidade e a diferença, isto é, um modo de pensar e de articular a identidade enquanto mesmidade e ipseidade discursivamente. Daí que a constituição e a noção de pessoa só poderá ser movente, dita narrativamente. Por esta razão, para Ricoeur,

sem a ajuda da narração, o problema da identidade pessoal está, com efeito, condenado a uma antinomia sem solução: ou se pensa um sujeito idêntico a si mesmo na diversidade de seus estados, ou, segundo Hume e Nietzsche, se sustenta que este sujeito não é senão uma ilusão substancialista, cuja eliminação não deixa lugar senão a uma pura diversidade de cognições, emoções e volições [...] Diferentemente da identidade abstrata do Mesmo, a identidade narrativa, constitutiva da ipseidade, pode incluir a mudança, a mutabilidade, na coesão de uma vida. ${ }^{75}$

Narrar implica "dizer quem fez o que, por que e como, mostrando no tempo a conexão entre esses pontos de vista". ${ }^{76}$ Para Ricoeur, "ao contrário da identidade abstrata do Mesmo, a identidade narrativa, constitutiva da ipseidade, pode incluir a mudança, a mutabilidade, na coesão de

70 PIVA, E. A. "A questão do sujeito em Paul Ricoeur", Síntese, 26 (1999), p. 209.

${ }^{71}$ Ibidem, p. 214.

72 MEYERHOFF, op. cit., p. 27.

73 PIVA, op. cit., p. 218.

74 RICOEUR, P. Temps et Récit, I, p. 85 apud PIVA, op. cit., p. 218, nota 17.

75 RICOEUR, Temps et Récit, I, apud PIVA, op. cit., p. 220.

${ }^{76}$ RICOEUR, P. O si-mesmo como um outro. Campinas, SP: Papirus, 1991, p. 174. 
uma vida. O sujeito mostra-se, então, constituído ao mesmo tempo como leitor e como escritor de sua própria vida". ${ }^{77} \mathrm{~A}$ identidade narrativa integra, numa dialética dialógica, o mesmo e o diferente, ser enquanto ato e potência. A identidade pessoal somente "constitui sua identidade numa estrutura relacional que faz prevalecer a dimensão dialógica sobre a dimensão monológica", ${ }^{78}$ de modo que ela não se apreende nem se constitui imediatamente, mas mediadamente, temporalmente. E essa perspectiva leva-nos a justificar uma metafísica narrativa. Nesta direção, o "Eu sou tem de se alcançar pela via dum trabalho de interpretação: 'a autoposição não é um dado, mas sim uma tarefa; ela não é gegeben, mas aufgegeben'". ${ }^{79}$

Ricoeur defendeu uma "ontologia do sujeito" que só pode ser pensada depois de passar pelo longo desvio da hermenêutica do si nas suas múltiplas determinações: linguística, prática, narrativa e ético-política. Sua reflexão é ontológica porque "está às voltas com a pergunta pelo ser, pelo ser do sujeito que pensa, que age, que sente, que vive. Para ele, o sujeito, antes de ser tomado e pensado como sujeito de conhecimento é 'afirmação originária [...] ato [de ser] mais do que forma, afirmação viva, poder de existir e de fazer existir"'. ${ }^{80}$ É possível dizer que é uma proposta metafísica, uma vez, que é pelo ato reflexivo que "o sujeito se retoma, se apreende e se identifica" o que revela seu modo de ser que não se dá imediatamente, e sim mediamente, ou seja, "não é possível que o sujeito dê conta de seu próprio ser por meio unicamente da atividade noético-reflexiva", todavia, é mediatizado "pela interpretação, pela hermenêutica dos signos, símbolos e textos nos quais o sujeito se objetiva [...] e a hermenêutica faz a mediação entre a fenomenologia e a ontologia". ${ }^{81}$ O exercício reflexivo é exercício metafísico, pois espelha e efetiva o modo de ser humano. Por isso, diferente da ontologia tradicional, Ricoeur propõe uma "ontologia emergente: o sujeito e a cultura, e os seus 'mundos' ou 'horizontes', advém pela via dum trabalho que descobre e cria, que explicita ou interpreta e transforma". ${ }^{82}$ Com sua ontologia emergente ou ontologia da desproporção ou ontologia quebrada [brisée], Ricoeur assinala, na verdade, sempre a "ausência de um 'sistema' que transparece através de uma preocupação pelo 'fragmentário' ou por uma 'sistematicidade quebrada'". ${ }^{83}$ José M. M. Heleno retoma as reflexões de

\footnotetext{
77 RICOEUR, P. Tempo e Narrativa. Tomo III. Campinas, SP: Papirus, 1997, p. 424-425.

78 RICOEUR, P. Le Juste, Éditions Esprit, 1995, p. 14 apud PIVA, op. cit., p. 228.

79 SUMARES, op. cit., p. 163-164 (grifos nossos).

80 PIVA, op. cit., p. 236.

81 Ibidem, p. 236-237.

82 SUMARES, op. cit., p. 281.

${ }^{83}$ HELENO, op. cit., p. 316.
} 
Juan M. N. Cordón e conclui que, de fato, em Ricoeur, "há uma ontologia em 'construção'" que "não é tanto a defesa de uma ontologia aberta e inacabada que se reivindica, mas sim o caráter preliminar e ainda imaturo desse mesmo projeto. Mais do que defender uma ontologia 'aberta', é antes a incapacidade de franquear os limites para aceder à ontologia que se confessa obstinadamente". ${ }^{84}$ Aqui, assinalamos nossa divergência com relação à proposta de Ricoeur, pois, antes de sustentar a vigência de uma ontologia ou metafísica provisória, reivindicamos e procuramos justificar a validade de uma metafísica narrativa, que é movente, aberta por causa do seu objeto marcado pelo tempo; ela não é apenas uma antecâmara, uma propedêutica à metafísica!

Diferentemente da tradição metafísica dogmática, abstrata e vazia, a metafísica narrativa, que justificamos a partir da tradição ricoeuriana, integra o tempo e a constituição da identidade humana numa trama em que, "cessando de viver na evidência do objeto", leva-nos a "apercebermos indissoluvelmente a subjetividade radical de toda nossa experiência e seu valor de verdade" ${ }^{85}$ Nesse caso, o homem não pretende ocupar o lugar do absoluto nem é subsumido ao longo do processo reflexivo, mas se torna pessoa que joga e é jogada pela linguagem. Jogando dessa maneira, alargam-se seus horizontes de compreensão, bem como sua possibilidade de ação, pois, ao jogar, ele toma consciência do tempo que é no tempo em que vive com pretensão de totalidade. A metafísica narrativa já não é mais "uma construção de conceitos por cujo intermédio tentaríamos tornar nossos paradoxos menos sensíveis", mas "é a experiência que temos deles em todas as situações da história pessoal e coletiva", de maneira que o discurso metafísico sustenta-se pela incessante "interrogação que não comporta respostas que a anulem [...] não é um conhecimento que viria terminar o edifício dos conhecimentos; é o saber lúcido daquilo que os ameaça e a consciência aguda de seu preço". ${ }^{86}$

\section{Algumas conclusões...}

Enfim, a metafísica, como um todo, não morreu nem poderá morrer, na medida em que "fazer metafísica não é entrar num mundo de conhecimento separado, nem repetir fórmulas estéreis", mas "é ter experiência plena dos paradoxos [...], é verificar sempre de novo o funcionamento discordante da inter-subjetividade humana, é procurar pensar até o fim os mesmos fenômenos investidos pela ciência, restituindo-lhes

\footnotetext{
${ }^{84}$ Ibidem, p. 319.

${ }^{85}$ MERLEAU-PONTY, op. cit., p. 187.

${ }^{86}$ PONTY, op. cit., p. 190.
} 
somente sua transcendência e estranheza originárias". ${ }^{87}$ A constituição da identidade humana diz-se, hermeneuticamente, segundo os moldes de uma linguagem que articula, dialeticamente, ser e devir, e nós somos no tempo. A metafísica precisa integrar, em sua construção, tanto a objetividade quanto a subjetividade, isto é, o sentido de[o] ser. Faço, aqui, minhas as palavras de Vattimo, para quem "a ontologia nada mais é que interpretação da nossa condição ou situação, já que o ser não é nada fora do seu 'evento', que acontece no seu e nosso historicizar-se". ${ }^{88}$

A ânsia de palavrear o real [o ser], de dar nomes aos nossos sonhos e desejos, é um sintoma do nosso modo metafísico de ser que procura superar a distância entre o que somos e nossas possibilidades sem a pretensão de eliminá-la, pois somos naturalmente separados de nós mesmos, fraturados, isto é, naturalmente metafísicos. Nessa perspectiva, a pessoa é "um lugar de perturbação, irrupção, solicitação" 89 . Visto dessa forma, morreu a metafísica que procurou eliminar a contradição da realidade, bem como a distância entre o que somos e desejamos ser, entre as palavras e as coisas. A linguagem metafísica apropriada à compreensão e à explicitação da finitude, da ambivalência e da contradição, "se encontra ante a tarefa de pensar a condição de possibilidade do todo não como necessária, mas como possível: trata-se de pensar a possibilidade da possibilidade", ${ }^{90}$ o que prepara e justifica o caminho da realização plena da liberdade e da historicidade humana. Nessa direção, a metafísica precisa empreender a via longa de acesso e de explicitação do real mediado pelo outro, pelos textos, pela reflexão.

O ser humano, ciente de que não "é criador da sua própria existência, encontrando-se já lançado no ser e a ser" tem, porém, "pela inteligência e pela vontade, o poder de cooperar na feitura de si mesmo, na elaboração da sua própria ontogênese, escolhendo-se e determinando-se através da iniciativa da liberdade. Introduz, assim, rupturas, descontinuidades, no decurso da sua existência temporal, através de decisões, atos inaugurais"; ele, desse modo, não é "pessoa, mas chamado a tornarse pessoa: a partir da existência, que precede a sua essência, ele tem de fazer-se o que é, conferir-se livremente a sua própria determinação, correspondendo à vocação fundamental para ser, que o distingue e o nobilita". ${ }^{91}$ É na linguagem narrativa que encontramos conservada e tensionada a imbricação entre a constituição da identidade pessoal e a concepção de tempo linear e cíclica que pauta a metafísica movente.

\footnotetext{
87 Ibidem, p. 192.

88 VATTIMO, G. O fim da modernidade. São Paulo: Martins Fontes, 1996, p. VIII.

89 CAPUTO, op. cit., p. 289.

90 VITIELLO, op. cit., p. 243.

91 BLANC, op. cit., p. 109-110.
} 
Enfim, tanto mais salutar e autêntica será a construção metafísica quanto mais assumir, do princípio ao fim de sua reflexão, o projeto de que, "no real da vida, as coisas acabam com menos formato, nem se acabam. Melhor assim. Pelejar por exato, dá êrro contra a gente. Não se queira. Viver é muito perigoso...". ${ }^{92}$

\section{Referências}

ARISTÓTELES. Metafísica. São Paulo: Loyola, 2002. Vol. II.

BENJAMIN, W. O narrador. In: 1980. (Os Pensadores). p. 142-154. . Textos escolhidos. São Paulo: Abril Cultural,

BLAMEY, K. Do ego ao si: um itinerário filosófico. In: HAHN, L. E. (Org.). A filosofia de Paul Ricoeur. Lisboa: Instituto Piaget, 1997. p. 83-126.

BLANC, M. F. Introdução à Ontologia. Lisboa: Instituto Piaget, s/d. . Metafísica do Tempo. Lisboa: Instituto Piaget, s/d.

BODIL, J. Dez considerações sobre o tempo. Rio de Janeiro: José Olympio, 2004.

BORNHEIM, G. Dialética: teoria e práxis; Ensaio para uma crítica da fundamentação ontológica da dialética. Porto Alegre, Globo; São Paulo: Editora da Universidade de São Paulo, 1983.

CAPUTO, J. D. Radical Hermeneutics: Repetition, deconstruction, and the hermeneutic project. Bloomington and Indianapolis: Indiana University Press, 1987.

COMTE-SPONVILLE, A. O ser-tempo. São Paulo: Martins Fontes, 2000.

GADAMER, H-G. Acerca da disposição natural do homem para a filosofia. In: A razão na época da ciência. Rio de Janeiro: Tempo Brasileiro, 1983. p. 78-87.

. Verdade e método I. Petrópolis, RJ: Vozes, 1997.

. Verdade e método II. Petrópolis, RJ: Vozes, 2002.

GLOY, K. Metaphysik - ein notwendiges oder vezichtbares Projekt?. In: (Hrsg.). Unser Zeitalter - ein postmetaphysisches? Würzburg: Königshausen \& Neumann $\mathrm{GmbH}, 2004$. p. 25-45.

GUIBAL, F. La métaphysique en question. Études, v. 351, p. 100-109, 1979.

HAHN, L. E. (Org.). A filosofia de Paul Ricoeur. Lisboa: Instituto Piaget, 1997.

HEIDEGGER, M. Os conceitos fundamentais da metafísica. Rio de Janeiro: Forense Universitária, 2003.

. Ensaios e conferências. 2. ed. Petrópolis, RJ: Vozes, 2001.

HELENO, José Manuel Morgado. Hermenêutica e ontologia em Paul Ricoeur. Lisboa: Instituto Piaget, 2001.

MADISON, G. B. "Ricoeur e a hermenêutica do sujeito". In: HAHN, L. E. (Org.). A filosofia de Paul Ricoeur. Lisboa: Instituto Piaget, 1997. p. 39-63.

MERLEAU-PONTY, M. O visível e o invisível. São Paulo: Perspectiva, 2003. . O metafísico no homem. São Paulo: Abril Cultural, 1980. (Os pensadores).

92 ROSA, op. cit., p. 82. 
L. Rohden - A metafísica repensada a partir da tradição ...

MEYERHOFF, H. O tempo na literatura. São Paulo: McGraw do Brasil, 1976.

NAYLA, F. A metafísica. Lisboa: Instituto Piaget, 1995.

PALMER, R. Hermenêutica. Lisboa: Edições 70, 1997.

PESSOA, F. Obra poética. Rio de Janeiro: Nova Aguilar, 1994.

PIVA, E. A. A questão do sujeito em Paul Ricoeur. Síntese, v. 26, p. 205-237, 1999.

PROUST, M. O tempo redescoberto. 10. ed. São Paulo: Globo, 1990.

RICOEUR, P. “Resposta a G. B. Madison”. In: HAHN, L. E. (Org.). A filosofia de Paul Ricoeur. Lisboa: Instituto Piaget, 1997, p. 63-65.

. A região dos filósofos. São Paulo: Loyola, 1996.

. O conflito das interpretações - ensaios de hermenêutica. Porto-Portugal: RÉS-

Editora, 1988.

. O si-mesmo como um outro. Campinas, SP: Papirus, 1991.

. Tempo e Narração - Tomo III. Campinas, SP: Papirus, 1997.

ROHDEN, L. "Hermeneutik: kritische Wiederaufnahme der Metaphysik mittels der Zeit?". In: EIDAM, H; HERMENAU, F; SOUZA, D (Org.). Metaphysik und Hermeneutik - Festschrift für Hans-Georg Flickinger zum 60. Geburstag. Kassel: Kassel University Press, 2004.

O tempo no tempo e na constituição da metafísica movente. Síntese, v. 33, p. 53-76, 2006.

ROSA, J. G. Grande Sertão: veredas. 2. ed. Rio de Janeiro: José Olympio, 1958.

SUMARES, M. O sujeito e a cultura na filosofia de Paul Ricoeur. Lisboa: Escher, 1989.

TRÍAS, E. La superación de la metafísica y el pensamiento del límite. In: VATTIMO, G. La secularización de la filosofía. Barcelona: Gedisa, 1994. p. 283-296.

TUROLDO, F. Verità del metodo. Padova: Il Poligrafo, 2000.

VATTIMO, G. O fim da modernidade. São Paulo: Martins Fontes, 1996.

. Metafísica, violencia, secularización. In: VATTIMO, G. (Comp.). La secularización de la Filosofía. Hermenéutica y posmodernidad. Barcelona: Gedisa, 1994. p. 63-88.

VAZ, C. H. L. Tópicos para uma metafísica do conhecimento. In: ULLMANN, R. A. (Org.). Consecratio Mundi. Porto Alegre: Edipucrs, 1998. p. 430-437.

VITIELLO, Vincenzo. Racionalidade hermenéutica y topología de la historia. In: VATTIMO, G. Hermenéutica y racionalidad. Barcelona: Grupo Editorial Norma, 1994. p. 211-244.

\section{Endereço postal:}

Programa de Pós-Graduação em Filosofia

Av. Unisinos, 950 - Cristo Rei

93022-000 São Leopoldo, RS, Brasil

Data de recebimento: 03/09/2013

Data de aceite: 10/09/2013 